\title{
Planned Criterion Group
}

National Cancer Institute

\section{Source}

National Cancer Institute. Planned Criterion Group. NCI Thesaurus. Code C93395.

A collection of conditions joined together via composition (ANDed) and/or optionality (ORed) to form a logical expression upon which the execution of an activity is based or upon which the cessation of a repeated activity is based, where components of the group may include other activities, observation results and/or other criterion groups, and where both the criterion group and its components are planned to be used at a particular point in a particular study. 